\title{
Property rights for social inclusion: Migrant strategies for securing land and livelihoods in Papua New Guinea
}

\author{
Gina Koczberski, ${ }^{1}$ George N. Curry ${ }^{1}$ and Ben Imbun ${ }^{2}$ \\ ${ }^{1}$ Department of Social Sciences, Curtin University of Technology, GPO Box U1987, Perth, \\ WA 6845, Australia. \\ ${ }^{2}$ School of Management, University of Western Sydney, Locked Bag 1797, Penrith South \\ DC, NSW 1797, Australia.
}

The reference for this article is:

Koczberski, G., Curry, G.N. and Imbun, B. (2009). Property rights for social inclusion: Migrant strategies for securing land and livelihoods in Papua New Guinea. Asia Pacific Viewpoint 50 (1) 29-42.

Please note that there may be some minor differences between this PDF version of the paper and the published article. Reprints of this article can be obtained from George Curry < g.curry“at”curtin.edu.au>

\begin{abstract}
This paper examines the broad range of informal land transactions and arrangements migrants are entering into with customary landowners to gain access to customary land for export cash cropping in the oil palm belt of West New Britain, Papua New Guinea. Whilst these arrangements can provide migrants with relatively secure access to land, there are instances of migrants losing their land rights. Typically, the land tenure arrangements of migrants with more secure access to land are within a framework of property rights for social inclusion whereby customary landowners' inalienable rights to land are preserved and the 'outsider' becomes an 'insider' with ongoing use rights to the land. Through socially embedding land transactions in place-based practices of nonmarket exchange, identities of difference are eroded as migrants assume identities as part of their host groups. This adaptability of customary land tenure and its capacity to accommodate large migration in-flows and expanding commodity production undermines the argument common amongst proponents of land reform that customary tenure is static and inflexible. Before such claims are heeded, there must be more detailed empirical investigations of the diverse range of land tenure regimes operating in areas of the country experiencing high rates of immigration.
\end{abstract}

Keywords: customary land tenure, gift exchange, informal land markets, migration, property law, social embeddedness

\section{Introduction}

This paper is concerned with the migration and settlement of large numbers of migrants seeking access to customary land ${ }^{1}$ for oil palm production and other livelihood activities in the oil palm belt of West New Britain Province (WNB), Papua New Guinea (PNG). The paper addresses two questions that are under-explored in the research on rural migration in the region. First, how do migrants as 'outsiders' without customary land-use rights obtain access to land to establish new livelihoods in their adopted homes? Second, how are customary land tenure arrangements being modified in response to the growing demand for land by 'outsiders' for agricultural development?

These questions are relevant to other rural areas of the developing world experiencing large in-flows of migrants seeking land. Across the developing world, people are leading more mobile lives as they migrate further afield and in larger numbers to seek new livelihood 
opportunities and experiences (Rigg, 2007). While much of this migration is rural-to-urban, a sizable proportion is rural-to-rural, particularly to agricultural and resource frontier zones. To provide this broader context and comparative material for the PNG case study, the paper begins with a brief overview of informal land markets in rural Southeast Asia and subSaharan Africa where large numbers of migrants are acquiring land for cash crop production, creating burgeoning informal land markets. This overview is followed by the PNG case study, beginning with an analysis of the main types of short and long-term land-use agreements negotiated between land-poor migrants and customary landowners in WNB. While these tenure arrangements can provide migrants with continuing and relatively secure access to customary land, there are many instances of migrants losing access rights to the land.

To understand why some migrants can successfully gain ongoing use rights to land while others continue to have insecure use rights, the paper draws on and extends Robert Cooter's (1991a) conceptual framework of land ownership in PNG which contrasts two types of ownership: 'property law for stranger relations' and 'property law for kin relations'. Customary landowners, while superficially engaging in a process of commodifying land through 'sales'2 and 'rentals' to migrants, are striving to socially embed land transactions by expecting migrants to maintain certain social and economic relationships with them as host lineages. For their validity, these relationships draw on place-based frameworks of land tenure in which social relations grounded in non-market exchange practices play a pivotal role in legitimising access rights. This process we term 'property rights for social inclusion' for it opens up opportunities for migrants to become a subgroup of the landowning group (to become insiders) which serves to erode identities of difference and bestow on migrants temporary or long-term access rights to land. Towards the end of the paper, we examine the extent to which these seemingly new types of land tenure arrangements emerging in rural WNB, sub-Saharan Africa and Southeast Asia, where there is high demand for land by outsiders, are modelled on old practices, customs and power relations. The paper closes with a brief discussion of the implications of the findings for recently mooted policies of land tenure reform in PNG.

\section{Migrants and informal rural land markets in the Global South}

Several scholars working in Indonesia have documented the sale of land to spontaneous migrants seeking land for cash crop production (e.g. Ruf and Yoddang, 1999; Elmhirst, 2001; Li, 2002; Potter and Badcock, 2004). In Central Sulawesi, Li (2002) charted the impact of the cocoa boom in the Lauje area in the early 1990s. Land was effectively privatised as a consequence of the cocoa boom because permanent tree crops broke the swidden cycle underpinning communal inheritance. This provided the basis for land to be treated as a commodity that could then be sold to migrants moving into the area.

In another case study from the Lindu area of Central Sulawesi where large concentrations of Bugis migrants have settled recently, Li reported that the indigenous population sold much of the land 'before they recognised its greatly enhanced value' (2002: 426). Why customary landowners would sell so much of their land to their own disadvantage is explained by Li as an indirect result of the uncertain legal status of customary land which enabled village headmen with authority in land matters to effectively dispossess customary landowners. Village headmen: 
apply various 'rules' which purportedly limit the validity of customary claims. They tell villagers that their customary rights lapse if the land has not been used for five years, or if the area exceeds 2 hectares, or if no tree-crops have been planted, or if the land has not been registered with the headman, or taxed, or issued with a certificate ( $\mathrm{Li}, 2002: 428$ ).

To receive some financial benefit before the land was sold off by the village headmen, villagers themselves began selling customary land to outsiders.

In a similar case from Sulawesi, Potter and Badcock (2004) described the loss of former customary swidden lands in the Rokan Hulu District, Riau Province, where, since the mid1980s, migrants had been purchasing land from customary landowners. Despite land sales being contrary to adat, most sales were legitimised through land ownership letters/certificates with the agreement of village officials and adat leaders. Approximately one-third of village land was purchased by outsiders, leaving villagers with insufficient land to practice 'traditional' farming. Much of the land sold to migrants was planted with oil palm and, to a lesser extent, with rice and rubber. Concern over the sale of agricultural land to migrants was also raised by Elmhirst (2001) working in the North Lampung transmigration resettlement areas of Sulawesi. The transmigration scheme introduced new farming systems and created an active land market as spontaneous migrants moved into the area and bought land either from transmigrants or local landowners. With the pressure on land for agricultural development, land values rose dramatically and speculative land dealings were on the increase.

Several themes are common to each of the Sulawesi case studies regarding the sale of land to migrants. These include the undermining and manipulation of the principles governing customary land tenure, emerging land shortages, the semi-formalisation of land transfers and the growing commodification of land. A comparable situation, though not to the same level of dispossession as reported in some of the Indonesian case-studies, has been documented in sub-Saharan Africa where the sale of agricultural land to migrants is occurring in many rural areas despite traditional prohibitions on the sale of customary land (e.g. Amanor and Diderutuah, 2001; Sjaastad, 2003; Daley, 2005; Chimhowu and Woodhouse, 2006; Hagberg, 2006; Peters, 2007; Yeboah, 2008). ${ }^{3}$

As in Indonesia, many rural land sales to migrants in sub-Saharan Africa are for the establishment of export cash crops and occur in the absence of formal land markets. Because such land transactions are not strictly in accordance with 'traditional' customary land laws, new rules and procedures have evolved to legitimise them and give them local validity, and evidence suggests that many remain embedded in the social relations and obligations underpinning 'traditional' land rights (Mathieu et al., 2002; Chauveau, 2006; Chimhowu and Woodhouse, 2006). ${ }^{4}$ Many land transactions often combine local cultural circumstances and mimic more legal processes operating in formal land markets. For example, Mathieu and colleagues (2002) noted informal land sales in Burkina Faso where the transfer of land was recorded on a written document signed by a local official, but without the words 'sell' or 'buy' mentioned because the sale of customary land is illegal in state law. In another example, Daley (2005) observed in her Tanzanian study that payments by the seller and purchaser to a village land committee to 'register' land transactions were, while technically illegal, tolerated because of their 'reference to the long-standing tradition in Uhehe that political leaders and land-allocating authorities were paid with "gifts" for their duties' (2005: 553). Similarly, Chimhowu and Woodhouse (2006) presented examples from West Africa of individuals strengthening the legitimacy of their purchases through investing in land 
improvements (e.g. tree planting, irrigation, continual use of land) - 'traditional' practices consistent with securing rights to customary land.

The sub-Saharan African material reveals the adaptability and malleability of customary land tenure in areas receiving large numbers of migrants. Furthermore, it indicates that the process of commodification does not necessarily involve a radical break with principles of customary land tenure, but rather a more evolutionary process of change in which both indigenous (informal) and introduced (formal) principles of land tenure are drawn upon to develop new land tenure arrangements and procedures to accommodate outsiders seeking land for agricultural development. However, as some of the Southeast Asian and African case studies reveal, there are inherent risks for customary landowners when village and political elites are able to manipulate principles of customary tenure to the disadvantage of ordinary villagers.

\section{West New Britain: From cocoa and copra to oil palm}

The oil palm belt on the northern coastal plain of WNB extends from Willaumez Peninsula to Open Bay near the East New Britain provincial border (Fig. 1). Most residents of the belt are heavily reliant on local resources for their everyday survival, especially land for gardening and commercial agriculture and, to a lesser extent, marine resources. Subsistence activities remain the cornerstone of village life where people rely on agriculture to meet most of their daily food requirements. Increasingly, terrestrial and marine resources are being used to generate cash incomes as people's material aspirations rise and cash becomes ever more important for meeting everyday needs.

Villagers have diverse livelihoods with many holding a range of export cash crops, including oil palm, cocoa and copra (Koczberski and Curry, 2003; Koczberski and Curry, 2005; Koczberski et al., 2006). Cocoa and copra were the first export cash crops to be planted by villagers and, until recently, they provided an important income source for rural households. Over the past decade, however, smallholder production of these crops has declined considerably because of declining market access which has compelled many villagers to diversify income sources. Many villagers turned to oil palm. Presently, the oil palm industry dominates the rural economy and is by far the most important commodity crop for smallholders and a major employer in the province. On several socioeconomic indicators, the oil palm growing areas in WNB rank highly relative to other rural areas of PNG (Hanson et al., 2001).

Over 77000 hectares of land are planted with oil palm in the two oil palm growing areas of Hoskins and Bialla (Table 1). Commercial plantings in the province began at Hoskins in the late 1960s following a World Bank recommendation that oil palm on a nucleus estate smallholder model be introduced to WNB to diversify the agricultural economy and increase the export income of PNG. The recommendation accorded at the time with the Australian administration's land settlement policies of the 1950s and 1960s to open up 'un-used' or 'under-exploited' land for the voluntary resettlement of rural people for the primary purpose of cash crop production. As part of these policies, large tracts of customary land along the north coast were alienated by the State and later used to develop the nucleus estatesmallholder projects at Hoskins and Bialla. 


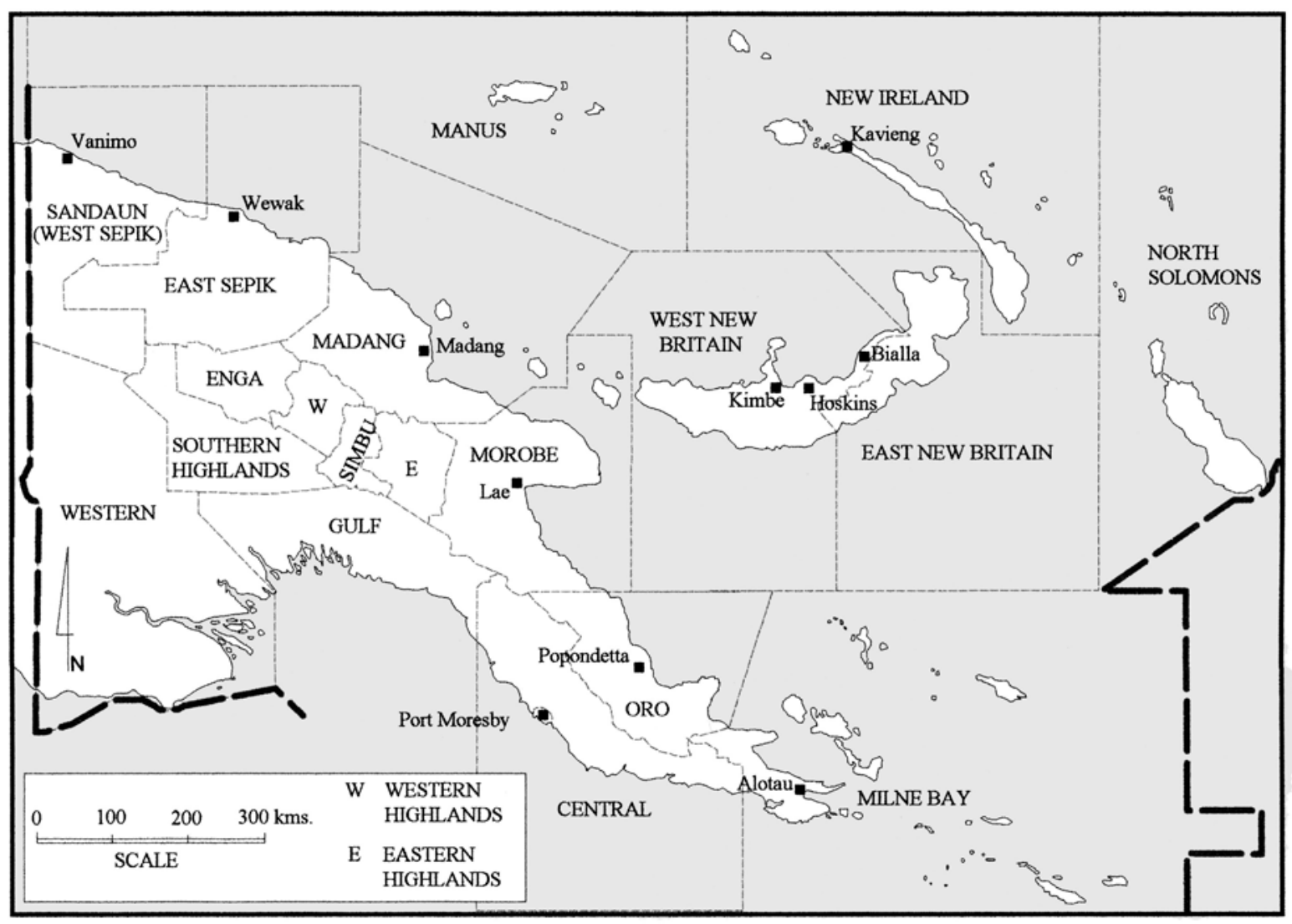

Figure 1. Location map of West New Britain Province

Table 1. Oil Palm Statistics for 2004-2005 for Hoskins and Bialla

\begin{tabular}{|l|l|l|l|}
\hline Oil Palm Statistics & Hoskins & Bialla & Totals \\
\hline $\begin{array}{l}\text { Smallholder production } \\
\text { (FFB tonnes) }\end{array}$ & 286145 & 134700 & 420845 \\
\hline Smallholder area (Ha)* & 24064 & 12026 & 36090 \\
\hline $\begin{array}{l}\text { Plantation production } \\
\text { (FFB tonnes) }\end{array}$ & $616135^{* *}$ & $144948^{* * *}$ & 761083 \\
\hline Plantation area (Ha)** & $30447^{* *}$ & $10929^{* * *}$ & 41376 \\
\hline
\end{tabular}
(2005/06 Figures supplied by OPIC. ${ }^{* *}$ Mini-estates included in plantation statistics. ${ }^{* * *}$ Community
Oil Palm Estate Development (COPED) included in plantation statistics.

The nucleus estate-smallholder model allowed for the establishment of smallholder land settlement schemes (LSSs), initially at Hoskins in 1968 and at Bialla in 1972. Settlers were recruited for the LSSs from other provinces of PNG and acquired individual 99-year state agricultural leases over blocks ranging from 4 to 6.5 hectares. Agricultural leases were publicly advertised with priority given to applicants from land-short areas of the country (Hulme, 1984; Curry and Koczberski, 1998). As the industry expanded, villagers living on customary land surrounding the nucleus estates were encouraged to plant two-hectare plots of oil palm as part of the Village Oil Palm (VOP) scheme. Planting by customary landowners was negligible in the early years, but has increased significantly over the last 20 years. 


\section{The pull of prosperity}

The relative prosperity of the oil palm economy is the basis for the high population growth rate in the region. Between 1980 and 2000, WNB's annual population growth of 3.7\% was among the highest in the country (National Statistical Office, 2001) due to both in-migration and a total fertility rate of over six. At the 2000 census, 30.5\% of the WNB population were migrants (National Statistics Office, 2001).

The large migrant population is concentrated in the Hoskins and Bialla oil palm LSSs and in the urban centres of Kimbe and Bialla. The LSSs have experienced considerable population growth since the late 1960s/early 1970s. Population density on the Hoskins LSS has risen from 5.9 persons per block in the early 1970s (Ploeg, 1972) to 13.3 persons per block (222 persons $/ \mathrm{km} 2$ ) in 2000, and in 2002 the Bialla LSS averaged 11.1 persons per block (185 persons $/ \mathrm{km} 2$ ). The oil palm belt also attracts many migrants from less well-off areas of the province and other regions of PNG who take up residence in informal urban settlements, on plantation compounds or with relatives on the LSSs. Excluding the highly densely populated islands of Bali Witu and Arawe, the oil palm belt from the Willaumez Peninsula to Navo has the highest population densities in the province, at up to 130 persons $/ \mathrm{km} 2$ (Hanson et al., 2001). Talasea Census District, which covers most of the oil palm belt, has a migrant population of $38 \%$ of the total population, the large majority of whom (79\%) have migrated from other provinces (National Statistical Office, 2001). Thus, a sizable proportion of the rural population in the oil palm belt do not have birth rights to land. ${ }^{5}$

\section{Changing land tenure arrangements}

Economic and demographic changes have been accompanied by marked alterations in land tenure. Aside from the alienated land under state agricultural leases described above, a wide range of overlapping tenure regimes/arrangements has emerged - informal, legal and illegal. While most village lands designated for oil palm cultivation are allocated by clan leaders and subject to the regulations of customary land tenure principles, the long-term cultivation of perennial cash crops can induce de facto changes in land tenure regimes. Usufruct rights are increasingly being vested in the same family or individuals for extended periods (smallholder oil palm is replanted at between 20 and 25 years of age), leading some villagers to claim exclusive rights of access to, and inheritance of, these resources. ${ }^{6}$ In effect, land rights are being 'individualised' as land is excised from the communal pool of clan land that is governed by communal tenure and matrilineal principles of inheritance.

As customary land tenure is modified, people's views and attitudes to land are changing such that land is increasingly being viewed by some clan members as a commodity that can be leased to oil palm milling companies, ${ }^{7}$ or informally 'sold ${ }^{8}$ or 'rented' to people outside the land-holding group. A discussion of these informal land 'sales' and 'rentals' is next.

\section{Settlers seeking land}

There is a large demand for land by migrants desiring to secure a future for their families in the WNB oil palm belt. There are few opportunities to purchase freehold land in the Bialla and Hoskins regions. While there has been a long history of customary landowners in the area gifting land to non-clan members, the informal 'sale' or 'renting' of land to migrants from other provinces in PNG is more recent. The 'sale' of customary land to migrants, in particular for the planting of oil palm, first emerged in the 1980s at Hoskins and in the early 1990s at Bialla. 
Most migrants 'purchasing' customary land wish to plant oil palm. They are usually the children or relatives of the original oil palm LSS leaseholders who migrated to WNB in the late 1960s and early 1970s, or are those in long-term employment (especially as oil palm plantation and mill labourers). On highly populated LSS blocks, many of the married sons of the original settlers are seeking land of their own to plant oil palm and raise their families. However, most second and third generation settlers are being squeezed out of the market for LSS blocks by rising prices and limited opportunities to accumulate savings on highly populated LSS blocks. Increasingly, those purchasing LSS blocks are urban-based professionals, successful businessmen, senior managers employed by the plantation companies, and occasionally, political elites. The current price of an LSS block at Bialla and Hoskins ranges from K5000 to K10 000 per hectare (K30 000 to K60 000 for a six-hectare block) compared with K500 to K3000 per hectare for customary land (K2.5 = Aus\$1.00, The Australian 21-22 July, 2007). Further, because opportunities for returning 'home' to settle are becoming more constrained through time, second generation settlers' attempts to secure additional land in WNB are becoming more urgent. Opportunities to re-establish themselves at 'home' are becoming remote because of their long absences, together with the fact that many of their children were raised in WNB and learned Melanesian Pidgin rather than their parents' home languages (Curry and Koczberski, 1999). Their home areas are also likely to be experiencing population and land pressures because settlers were initially recruited from land-short areas. Similarly, company employees who have spent much of their working lives in WNB and who identify more closely with WNB than 'home' (their children were raised in WNB), aspire to securing a livelihood in 'retirement' by purchasing land. Thus, for the majority of second generation settlers and migrant workers, the purchase of customary land in WNB is their only real option, apart from illegally occupying rural State land or moving into an informal settlement in town.

Within the oil palm schemes of Bialla and Hoskins, approximately 200 hectares and 2721 hectares of customary land respectively have been 'sold' to 'outsiders' for oil palm development, typically as two- or four-hectare blocks. The planting of oil palm by migrants on 'purchased' customary land has expanded markedly over the past 10 years, with approximately $23 \%$ of the total area of oil palm established on customary land in the Hoskins area now 'owned' by outsiders. While there are formal procedures for the sale or transfer of customary land, in almost all cases, land transactions are organised informally. ${ }^{9}$ Hence, there is great variation in the types of informal land sale agreements which is partly explained by the different types of relationships between 'vendors' and 'purchasers' (see below). Most 'sales' are verbal agreements without documentary evidence of the clan's approval of the land transaction nor any written record of the agreed sale price, size and boundary of the parcel of land sold or deposit paid: most transactions involve an initial deposit followed by payment instalments that may be spread over several years while the 'purchaser' resides on the land. Many migrants view the 'purchase' of land as conferring ownership in perpetuity which will allow their children to inherit the land. This is not the case in law as the land remains customary land with the potential for the block to be reclaimed by the customary landowners on the death of the 'purchaser' (Curry et al., 2007).

Indeed, there have been numerous cases of migrants being evicted or harassed by members of the landowning group, especially by younger clan members, and instances where the land 'purchased' by migrants has been reclaimed by the customary landowners (Koczberski and Curry, 2004; Curry and Koczberski, 2009). In May 2006, the District Court in Kimbe ruled in favour of a landowning group for the return of land illegally 'sold' to migrants by an 
individual from a neighbouring landowner group (J. Warku, pers. comm., 2000). Over 100 migrant families face eviction from the land they had 'purchased' and planted to oil palm. That some migrants are willing to pursue the risky strategy of acquiring customary land is indicative of the social and economic pressures on second generation leasehold migrants and plantation/mill labourers, and the limited economic futures they would face if they were to return to their home provinces. ${ }^{10}$

The least financially risky option for land-poor migrants is to informally 'rent' land from customary landowners. Typically, migrants 'rent' a small plot of land for a house site in a small community of migrants to whom they are usually related, and an additional nearby small plot of land for garden food production. These settlements are on customary land or state land, ${ }^{11}$ and are usually less than two to three hectares. Many of these migrants informally 'renting' land from the customary landowners have previously worked as oil palm labourers and many of them have relatives living on the LSSs, company residential compounds or on 'purchased' land. The numbers of residents and erected houses in the settlement, and the size and locations of food gardens are monitored and controlled by the customary landowners.

The term 'rent' is used here to define a set of highly variable informal arrangements between landowners and migrants that provide migrants with temporary and tightly defined access rights to the customary land of their hosts. Both parties are clearly aware that the 'rental' agreement is a temporary arrangement (though some have been in place for over 20 years), and that the underlying ownership of the host lineage is not undermined through occupancy and use. These 'rental' agreements are typically based on indigenous exchange relationships, whereby migrants gain occupancy rights and the right to erect semi-permanent houses, cultivate food gardens and, occasionally, in special circumstances, to plant permanent cash crops in return for a 'rental' payment in the form of cash, labour, garden foods and/or participation in communal events. The size and frequency of payments of cash, labour and food items vary greatly between settlements, between households within settlements and through time, and are often dictated by the needs of the host lineages at particular points in time, and the landowner's relationship with the head of the settlement. For example, it is not unusual for landowners to visit settlements to raise money for large customary events such as mortuary or brideprice payments.

Different sets of rules apply to 'rented' land used for commercial purposes. As mentioned above, the planting of permanent cash crops is rarely permitted and occurs only when there is a strong and long-term friendship between migrant and host, or the migrant is related to the host (e.g. as an in-law). Generally, migrants 'renting' land are precluded from building up a permanent claim of ownership to the land by being denied rights to plant perennial cash crops and coconut palms. Other income generating activities such as commercial peanut production (a cash crop sold at local markets), vanilla cultivation, or the establishment of small businesses such as tradestores or poultry production and sales are generally prohibited. If these income-generating activities are permitted, it is expected that the income from these businesses will be shared with the landowners or that other obligations to the hosts are fulfilled. In one informal settlement on state land near Bialla town, occupied by migrants from Southern Highlands Province, the original customary landowners of the land were illegally collecting monthly 'rents' on two poultry businesses and one tradestore in the settlement. According to the tradestore proprietor, the hefty rental fees on the tradestore significantly eroded his profits on the business, and after 12 months of operation the store closed. In a nearby informal settlement on 'rented' customary land, one of the customary 
landowners had recently approached the East Sepik migrants leasing the land with an offer of two hectares of land which they could use to cultivate peanut gardens for two years. The landowner asked the residents to do the laborious tasks of clearing the secondary forest on the land and planting his oil palm seedlings. In return, they could interplant the oil palm seedlings with peanuts for sale at local markets. In this case, the landowner benefited from the access to in-kind labour to clear and plant the site to oil palm, as well as two years of additional labour to weed the site during the establishment phase of the oil palm. For the migrants, there were potentially high incomes to be earned from cultivating and marketing the peanuts.

Thus, the basic and typical land-use rights extended to migrants through informal 'rental' agreements permit the temporary occupation of land, the erection of houses and the cultivation of food gardens, with wealth generating activities on the land more strictly controlled. In some situations, these small settlements on 'rented' land can become closely aligned with a particular segment of the host community such as the lineage or subclan of the clan leader who provided initial access to the land. The settlement community can therefore become an important support base for village leaders or aspiring leaders. These small settlements allow these leaders in the host community to advance their social and political position by providing them with political support and a source of labour, cash and wealth items to be deployed through indigenous exchange networks to enhance their status and position. In the longer-term, they provide a possibility for the 'privatisation' or 'individualisation' of communal resources.

\section{Insiders/outsiders and property rights for social inclusion}

Customary land purchases sometimes end in dispute after a few years. Ownership disputes arise from two conflicting interpretations of land transactions: an introduced view of land as a commodity with exclusive and alienable rights over a defined area of land; and an indigenous view of land as an inalienable resource held by the kinship group, and where a range of use rights to separate resources may be held simultaneously by different people and groups. Many settlers and other outsiders seeking to acquire customary land approach the transaction as if it were largely a market transaction involving the purchase of exclusive and alienable rights to the land. Accordingly, the transaction is interpreted by the migrant as conferring on him individual ownership similar to freehold title.

The second perspective - the indigenous view of land as an inalienable resource held by the kinship group - is common among members of the customary landowning group. In this view, exclusive and permanent property rights are not guaranteed by full payment of the agreed 'purchase' price. Instead of land rights being permanent and exclusive, a less exclusive set of rights pertain that are conditional for their ongoing validity on continued participation in customary exchange activities and fulfilling other obligations to their hosts. Accordingly, they are expected to share a portion of their wealth with the landowning group by contributing to bride wealth, mortuary payments and to other forms of indigenous exchange in which their host lineages are involved. Involvement in community events is also expected. When participation in exchange activities with host lineages ceases, the validity of settlers' tenure rights begins to erode with a gradual reversal of rights back to the host lineage. 
Robert Cooter's (1991a) conceptualisation of the differences between freehold and customary tenure in PNG (Fig. 2) can be usefully applied to the two different interpretations of land transactions described above. Cooter described freehold transactions as those that occur largely between strangers whose only relationship with each other is commercial and the obligations and commitments to each other are minimal. While buyers and sellers have some obligations to each other, based on moral norms of societal behaviour, the transaction choices they make are not constrained by social obligations to each other. Both parties can act to their own best advantage and the relationship between them is short-term and concludes with completion of the sale. Freehold tenure is thus conceived as 'property law for stranger relations' (Cooter, 1991a: 41). In contrast, customary land tenure transactions occur between relatives and are based on long-term relationships of reciprocal obligations, cooperation and commitment to members of the kinship group (Fig. 2). Such obligations and commitments affect customary rights to land and constrain a person's freedom to act to their own best advantage in land transactions. Cooter (1991a: 41) describes customary land law as 'property law for kin relations'. Under customary land law, the concept of property is relational and ownership rights are dispersed among the kinship group. This is in contrast to freehold title where ownership is unitary and absolute, and land transactions are grounded in market relationships.

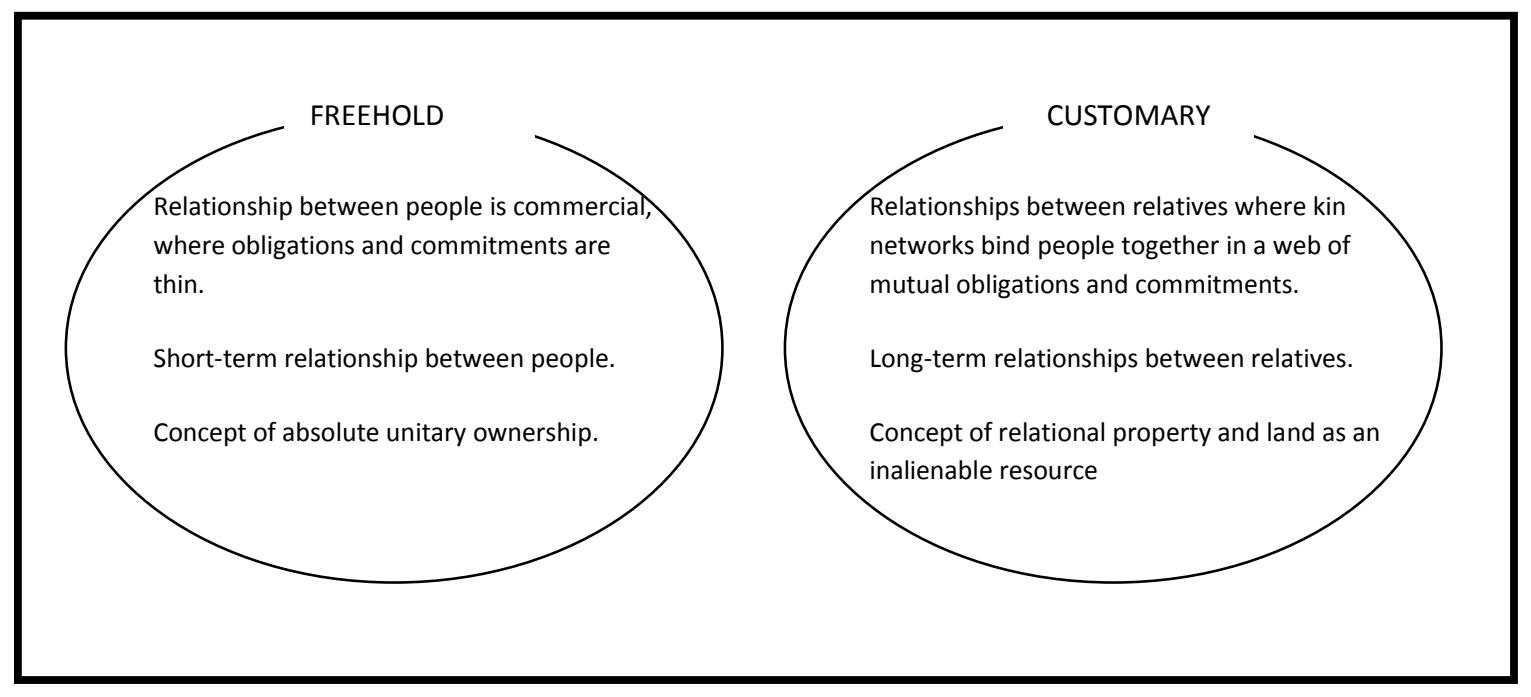

Figure 2. Cooter's concept of property law in PNG

Many settlers purchasing land are attempting to discursively construct the land transaction as being in the realm of commodity exchange thereby associating the transaction with principles of freehold title (stranger relations). They attempt to limit their relationships with landowners, and are also more likely to experience challenges to their tenure and harassment by local youth. For the outsider acquiring land there are several advantages if the transaction is understood by the customary landowners as a market transaction in which the land parcel, as a commodity, has been alienated from customary ownership. From this perspective, the land is held in perpetuity by the purchaser and is therefore able to be inherited by his children on his death. He has absolute control over the land including land use (any income activity does not lead to claims by the customary landowners for a share of that wealth), disposal of land (the land can be sold or leased to someone else), and there are no obligations on him to 
maintain a social relationship with his 'hosts' through gifts of labour and wealth. All obligations cease with the final payment instalment for the land. It is possible that clan leaders eager to sell land encouraged this perception among migrants purchasing land. Likewise, it is possible that this view is derived from migrants' experiences of living on government leasehold LSSs where they have had no social or financial obligations to the former customary landowners. It is this ideal that some migrants are trying to recreate on customary land, and in so doing often resist or reject demands placed on them by local landowners for occasional gifts of cash or contributions of labour or food to community events.

The demands placed on 'purchasers' by customary landowners accord more with the common and widespread view of land ownership in PNG which is based on customary law (property law for kin relations) and the set of mutual obligations that are required to maintain access rights to the land. Furthermore, these rights may be graduated such that a person or group has more authority than another in determining land use, or one group may hold rights to hunt or plant temporary food gardens, but may not have rights to plant permanent cash crops. As in most parts of PNG, customary ownership of land is not based purely on descent, but also on co-residence and participation in indigenous exchange (see Cooter, 1991a; Larmour, 1991; Curry, 1997). Settlers 'purchasing' land are thus expected to act like members of the landowning group and follow indigenous rules of kinship and clanship. However, it is important to note that this performance of host clan membership is not on an equal footing with the host clan or lineage, but is from a subservient position in which the wealth and labour power of migrant guest lineages is siphoned to host lineages.

\section{Becoming an insider}

The demands on purchasers by customary landowners could be interpreted as attempts by landowners to 'indigenise' these land transactions by transforming commodity transactions (property law for stranger relations) into indigenous exchange transactions (property law for kin relations). In other words, some customary landowners are attempting to socially embed these transactions by reinserting the social dimension of indigenous exchange into what are considered, at least by some migrants, to be market transactions with strangers. By doing so, customary landowners are developing long-term relationships with purchasers (outsiders) through incorporating them into networks of obligations and exchange with their host community. In the process, they become a subgroup attached to the host group which confers on them certain rights and privileges including ongoing access to land. This process we have termed ‘property rights for social inclusion' (Fig. 3).

Those settlers accepting land transactions to be grounded in social relationships (socially embedded) and acting in accordance with traditional rules and expectations generally have relatively stable relationships with their host communities and ongoing access to land. The exchange relationships, in which migrants engage, strengthen their social networks with the landowning group and socially integrate them in their host communities. Furthermore, the individuals and lineages within the landowning group with whom they have exchange relationships become obligated to strengthen these settlers' identities and positions within the broader host group.

Within this framework of property rights for social inclusion, customary landowners' inalienable rights to land are preserved and the outsider becomes an insider with ongoing use rights to the land. Thus, what were initially market transactions in land and partly disembedded from their social context are now made social and re-embedded through place- 
based practices of non-market exchange which serve to erase identities of difference. This type of land 'purchase' based on social exchange and inclusion is what underlies land that is gifted or informally 'rented' to outsiders. Few migrants acquiring land in this way question such obligations and the commitments to their hosts.

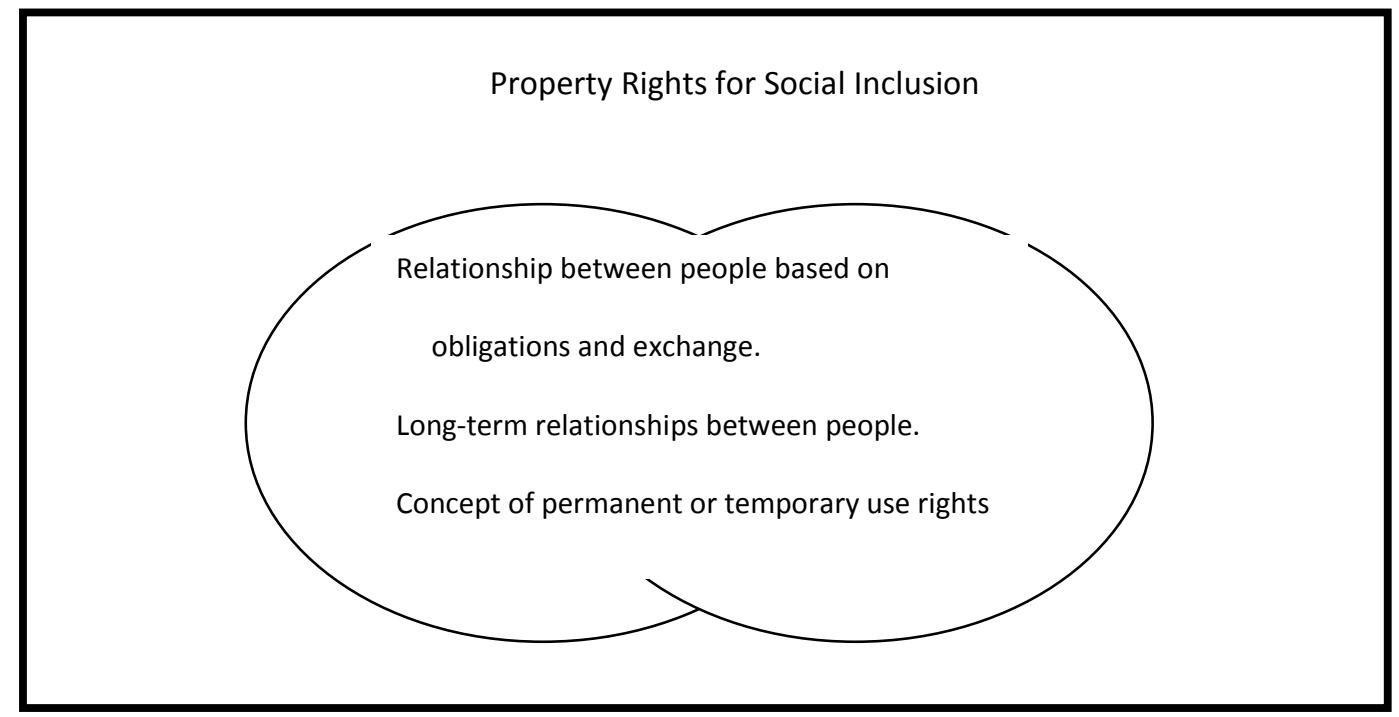

Figure 3. Property rights for social inclusion

While these relationships can be enduring, they can sometimes be re-assessed at the death of either the clan leader or the migrant involved in the initial land transaction, or at the replanting stage when palms are about 20-25 years old. These events are potential rupture points in the web of social and generational relationships underpinning resource access because established patterns of social and exchange relationships partially dissolve to reform as new webs of social relationships. It is at these junctures that the status and value of relationships between 'outsiders' and their 'host' lineages are re-assessed and the land rights of outsiders may be renegotiated or even cancelled (see Curry and Koczberski, 2009). While the degree of exploitation of the relationships underpinning land access through property rights for social inclusion have yet to be determined, it does not appear that economic exploitation of migrants by their hosts has become too onerous. ${ }^{12}$ Many migrants reported that the social embedding of these relationships provided them with a sense of belonging in the broader host community, even though there was a dependency associated with the relationship and host groups retain ultimate authority over the land.

\section{Novel but not new}

At one level, the 'sale' and 'renting' of land in WNB can be viewed as a process of commodification, but as argued above such land transactions remain, at least from the perspective of most customary landowners, anchored in principles of indigenous land tenure and longstanding concepts of clan identity, social inclusion and entitlements.

Contemporary land-use agreements between customary landowners and outsiders in WNB appear comparable with traditional mechanisms of transferring land rights to individuals and 
lineages without birth rights to the land reported operating in other parts of the country (Meggitt, 1965, 1971; Reay, 1971; Mandeville, 1979; Mosko, 2005). Anthropologists as early as the 1950s observed that while an ideology of descent (primacy of birth rights) was present in many PNG societies, social organisation was often sufficiently flexible to accommodate a high proportion of outsiders/immigrants (e.g. Barnes, 1967: 40; also Barnes, 1962; Forge, 1972). Often, immigrants utilised indigenous exchange relationships with host lineages for ongoing resource access (Reay, 1959a,b; Glasse, 1968; Forge, 1972; Healey, 1979; Mandeville, 1979; Sillitoe, 1979; McDowell, 1980; Curry, 1997). Through participation and cooperation in such exchange relationships, outsiders' membership in land-holding groups was facilitated. Thus, while the 'sale' of land to migrants for the cultivation of introduced cash crops such as oil palm and the informal 'renting' of land involve new types of land tenure arrangements, they are symbolically and materially modelled on old practices and customs that historically may have been widespread in PNG.

The evidence from sub-Saharan Africa, presented earlier, paints a similar picture to the PNG situation where new forms of land tenure, based on the 'rental' or 'sale' of land to outsiders are typically modelled on old practices. For example, it was traditionally the case in rural areas of West Africa that 'strangers' could obtain temporary access to farming land through the provisions of customary land tenure that allowed the granting of land to those in need (Mathieu et al., 2002: 111). Such access rights were conditional on the maintenance of particular relationships and forms of respect and gratitude, expressed as 'gifts' that validated land rights. As Mathieu and colleagues (2002) explain, access to land by 'strangers':

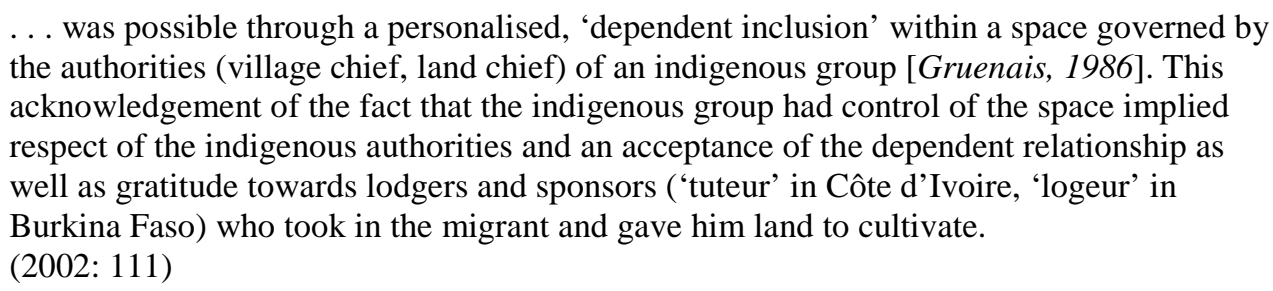

Even in the cocoa growing areas of West Africa where sharecropping agreements have operated since the colonial period to allow migrants access to land for cocoa farming, there is a growing market in land rentals and sales, which Chimhowu and Woodhouse (2006: 354) view as a 'logical progression' flowing from sharecropping agreements. Thus, many of the present day land transactions involving the sale and rental of land to migrants in West Africa appear to reflect more 'traditional' and colonial influenced mechanisms for allocating customary land to outsiders (see also Chauveau, 2006; Hagberg, 2006). Furthermore, as noted above, while these shifts in land tenure seem to involve evolutionary change towards increasing commodification, the process remains to a large extent embedded in social relationships (Mathieu et al., 2002: 126; Chimhowu and Woodhouse, 2006) and could be viewed as a form of property rights for social inclusion that serve to erase identities of difference between customary landowners and 'outsiders'.

While the land transfers in the Southeast Asian case studies do not appear to represent old practices and customs to the same extent as they do in PNG and sub-Saharan Africa, they do reveal the ways in which principles of customary land tenure can be manipulated by village elite to allow the sale of land. This is also operating in some situations in WNB and West Africa where clan or village leaders are largely responsible for land transactions with migrants. 


\section{Conclusion}

This paper has examined the processes by which migrants in the oil palm belt of WNB gain access to customary land for export cash cropping and how customary land tenure is being modified to accommodate this rising demand for land. Superficially, these land transactions appear to involve the commodification of customary land. On closer scrutiny, it is revealed that they are often mediated by place-based frameworks of land tenure in which social relationships and non-market values play a critical role. These land transactions, which are within a framework of property rights for social inclusion, enable migrants to forge a social identity as part of the host group that moves them from the position of outsiders to insiders and in the process strengthens their access rights to land. Thus, how migrants manage their relationships with customary landowners is important for determining their identity, status and position in relation to the host group.

There are important implications for policies of land tenure reform arising from the malleability of customary land tenure in the context of high rates of immigration, rapid social change and expanding commodity production. In the PNG and sub-Saharan African cases, emerging forms of land tenure did not require a radical break with traditional regimes of customary tenure to accommodate migrants pursuing new types of livelihoods based on cash cropping. Traditional tenure regimes are not static and inflexible as often portrayed by proponents of land reform who claim land registration and titling will boost agricultural productivity. In both PNG and Africa where there is pressure to introduce customary land reform policies, the dynamic nature of customary land tenure and its capacity to accommodate change is either ignored or downplayed (see edited collection by Fingleton (2005b) for a review of these debates in PNG, and Peters (2007) for sub-Saharan Africa).

For proponents on both sides of the debate, there must be a better understanding of what is to be gained and lost through policies of land tenure reform. This will require detailed empirical analyses of the nature and content of the diverse range of new land tenure regimes that are emerging in rural (and urban) areas experiencing high rates of immigration and/or agricultural development. These should be described and evaluated carefully before embarking on a consideration of the need for land reform policies. Such a process would entail, among other things, investigating what a 'sale' or land 'rental' means for the parties making the transaction including the broader community of customary landowners; what it is that is being 'sold' or 'rented'; and, the extent to which land is being alienated from customary ownership. For example, do 'sales' mean complete alienation of land as described by Li (2002) and Potter and Badcock (2004) in Sulawesi? Or, does the term mean something less than full alienation as in the WNB case study and in some of the African studies described above?

The paper also raises several other research questions regarding land transactions between migrants and customary landowners. For example, how will land rights, built up by migrants over many years through both market and indigenous exchange transactions, be managed or regulated by the State, migrants and customary landowner groups, especially given the lack of legal status of many land dealings and the emergence of land shortages in some areas? How will inheritance, the replanting of senile stands of oil palm and the 'sub-letting' of 'purchased' blocks in WNB be managed by customary landowners, the oil palm industry and provincial land administrators? And, finally, how can emerging land tenure regimes be kept within a framework of property rights for social inclusion that provides some level of tenure 
security for migrants acquiring land while recognising and preserving the underlying rights of customary landowners?

\section{Acknowledgements}

The paper benefited from feedback from participants at two conferences: the Curtin RUSSICMiri conference, Borneo, in February 2007, and the ASAO conference, Canberra, in January 2008. We thank guest editor, Associate Prof. Fadzilah Majid Cooke, for bringing this special section of the journal to fruition. The Department of Geography, University of Copenhagen, provided a congenial home for the final revisions of the paper to incorporate the insightful comments of referees. Finally, we thank the many smallholder families and customary landowners who shared with us their knowledge and experiences of land dealings in WNB. The research was funded by an ARC Discovery Project grant with supplementary data collected during a separate smallholder study with the PNG Oil Palm Research Association funded by the Australian Centre for International Agricultural Research.

\section{Notes}

1 Almost $97 \%$ of land in PNG is held communally under customary tenure with access rights based on a mixture of descent, co-residence and participation in communal activities. State intervention is limited on customary land. Fingleton's (2004) description of customary land tenure in PNG applies to WNB: 'a balance between group and individual rights and obligations, with land ownership being held at a group level and land use being exercised at the individual or household level' (Fingleton, 2004: 112 quoted in Fingleton 2005a).

2 We use inverted commas to refer to land 'sales', 'purchases' and 'rentals' where their usage in the text does not correspond with their exact meaning in English.

3 While land sales to migrants are common, the long-term rental of land and accessing land through sharecropping is much more widespread among migrants in Sub-Saharan Africa. In some parts of Africa these mechanisms for accessing land have been operating for more than a century (Chimhowu and Woodhouse, 2006).

4 This should not be interpreted to mean that customary tenure principles are free of manipulation by powerful village chiefs or local political leaders in land dealings with migrants.

5 The census data for migrants in the Talasea Census District do not include second or third generation migrants born within the District. Thus, the proportion of the rural population without birth rights to land is much higher.

6 Typically, under traditional principles of land tenure, when a food garden is abandoned to fallow after several years of cultivation, land tenure reverts to the group.

7 Lease arrangements in oil palm developments enable customary landowners to enter into long-term joint agricultural ventures with private investors through the lease, lease-back provisions of the 1996 Land Act (see Koczberski et al., 2001).

8 Section 81 of the Land Act prohibits the sale of customary land except to citizens of PNG in accordance with customary law. According to Cooter (1991b), most magistrates in PNG do not believe that customary law allows sales of land to people outside the kinship group.

9 People buying customary land to establish oil palm in the Hoskins scheme are encouraged to follow a set of land sale procedures introduced recently by the extension organisation, the Oil Palm Industry Corporation (OPIC) (see Curry et al., 2007 for details).

10 In many rural areas of PNG, health and education services and road infrastructure have deteriorated, and there are few employment opportunities. 
11 The state land is 'rented' to migrants by the original customary landowners.

12 For a description of a PNG case study in which these relationships have become highly exploitative, see Curry (1997).

\section{References}

Amanor, K. and M. Diderutuah (2001) Share contracts in the oil palm and citrus belt of Ghana. London: International Institute for Environment and Development.

Barnes, J.A. (1962) African models in the New Guinea highlands, Man 2: 5-9.

Barnes, J.A. (1967) Agnation among the Enga: A review article, Oceania 38: 33-43.

Chauveau, J.P. (2006) How does an institution evolve? Land, politics, intergenerational relations and the institution of the Tutorat amongst autochthones and immigrants (Gban region, Côte d'Ivoire), in R. Kuba and C. Lentz (eds.), Land and the Politics of Belonging in West Africa, pp. 213-241. Leiden: Koninklijke Brill NV.

Chimhowu, A. and P. Woodhouse (2006) Customary vs private property rights? Dynamics and trajectories of vernacular land markets in sub-Saharan Africa, Journal of Agrarian Change 6(3): 346-371.

Cooter, R.D. (1991a) Kin groups and the common law process, in P. Larmour (ed.), Customary land tenure: Registration and decentralisation in Papua New Guinea, pp. 3349. Monograph 29, Port Moresby: Papua New Guinea Institute of Applied Social and Economic Research.

Cooter, R.D. (1991b) Inventing market property: The land courts of Papua New Guinea, Law and Society of Review of 25(4): 759-801.

Curry, G.N. (1997) Warfare, social organisation and resource access amongst the Wosera Abelam of Papua New Guinea, Oceania 67(3): 194-217.

Curry, G.N. and G. Koczberski (1998) Migration as a way of life for the Wosera Abelam of Papua New Guinea, Asia Pacific Viewpoint 39(1): 29-52.

Curry, G.N. and G. Koczberski (1999) The risks and uncertainties of migration: An analysis of recent trends amongst the Wosera Abelam of Papua New Guinea, Oceania 70(2): 130 145.

Curry, G.N. and G. Koczberski (2009) Finding common ground: Securing land in the oil palm frontier of Papua New Guinea, Geojournal 175(2), 98-111.

Curry, G.N., G. Koczberski, E. Omuru, J. Duigu, C. Yala and B. Imbun (2007) Social assessment of the smallholder agriculture development project. Report prepared for World Bank.

Daley, E. (2005) Land and social change in a Tanzanian village 2: Kinyanambo in the 1990s, Journal of Agrarian Change 5(4): 526-572.

Elmhirst, R. (2001) Resource struggles and the politics of place in North Lampung, Indonesia, Singapore Journal of Tropical Geography 22(3): 284-306.

Fingleton, J. (2004) Is Papua New Guinea viable without customary groups? Pacific Economic Bulletin 19(2): 96-103.

Fingleton, J. (2005a) Introduction, in J. Fingleton (ed.), Privatising land in the Pacific. A defence of customary tenures, pp. 1-5. Canberra: The Australia Institute.

Fingleton, J. (ed.) (2005b) Privatising land in the Pacific. A defence of Customary Tenures. Canberra: The Australia Institute.

Forge, A. (1972) The golden fleece, Man 7(4): 527-540.

Glasse, R.M. (1968) Huli of Papua. A Cognatic Descent System. The Hague: Mouton and Co. Hagberg, S. (2006) Money, ritual and the politics of belonging in land transactions in Western Burkina Faso, in R. Kuba and C. Lentz (eds.), Land and the Politics of Belonging in West Africa, pp. 99-118. Leiden: Koninklijke Brill NV. 
Hanson, L.W., B.J. Allen, R.M. Bourke and T.J. McCarthy (2001) Papua New Guinea rural development handbook. Canberra: Land Management Group, Department of Human geography, The Australian National University.

Healey, C.J. (1979) Assimilation of nonagnates among the Kundagai Maring of the Papua New Guinea highlands, Oceania 50(2): 103-117.

Hulme, D. (1984) Land settlement schemes and rural development in Papua New Guinea. Unpublished PhD thesis. Queensland: James Cook University.

Koczberski, G. and G.N. Curry (2003) Sustaining production and livelihoods among oil palm smallholders: A socio-economic study of the bialla smallholder sector, Perth: Research Unit for the Study of Societies in Change, Curtin University of Technology. Retrieved 14 September 2007, from Website: http://espace.lis.curtin.edu.au/archive/00000233/

Koczberski, G. and G.N. Curry (2004) Divided communities and contested landscapes: Mobility, development and shifting identities in migrant destination sites in Papua New Guinea, Asia Pacific Viewpoint 45(3): 357-371.

Koczberski, G. and G.N. Curry (2005) Making a living: Land pressures and changing livelihood strategies among oil palm settlers in Papua New Guinea, Agricultural Systems 85(3): 324-339.

Koczberski, G., G.N. Curry and K. Gibson (2001) Improving productivity of the smallholder oil palm sector in Papua New Guinea. Canberra: Department of Human Geography, Research School of Pacific and Asian Studies, Australian National University. Retrieved 14 September 2007, from Website: http://espace.lis.curtin.edu.au/archive/00000235/

Koczberski, G., G.N. Curry, J.K.Warku and C. Kwam (2006) Village-based marine resource use and rural livelihoods: Kimbe Bay, West New Britain, Papua New Guinea, TNC Pacific Island Countries Report No 5/06. Brisbane: The Nature Conservancy, Indo-Pacific Resource Centre. Retrieved 14 September 2007, from Website:

http://espace.lis.curtin.edu.au/archive/00001105/

Larmour, P. (1991) Registration of customary land: 1952-1987, in P. Larmour (ed.), Customary land tenure: Registration and decentralisation in Papua New Guinea, Monograph 29, pp. 51-72. Port Moresby: Papua New Guinea Institute of Applied Social and Economic Research.

Li, T.M. (2002) Local histories, global markets: Cocoa and class in upland Sulawesi, Development and Change 33(3): 415-437.

Mandeville, E. (1979) Agnation, affinity and migration among the Komno of the New Guinea highlands, Man 14: 105-123.

Mathieu, P., M. Zongo and L. Paré (2002) Monetary land transactions in Western Burkina Faso: Commoditisation, papers and ambiguities, The European Journal of Development Research 14(2): 109-128.

McDowell, N. (1980) It's not who you are but how you give that counts: The role of exchange in a Melanesian society, American Ethnologist 7: 58-70.

Meggitt, M. (1965) The lineage system of the Mae-Enga of New Guinea. London: Oliver and Boyd.

Meggitt, M.J. (1971) The pattern of leadership among the Mae Enga of New Guinea, in R.M. Berndt and P. Lawrence (eds.), Politics in New Guinea, Perth: University of Western Australia Press.

Mosko, M. (2005) Customary land tenure and agricultural success: The Mekeo case, in J. Fingleton (ed.), Privatising land in the Pacific.A defence of customary tenures, pp. 16-21. Canberra: The Australia Institute.

National Statistical Office (2001) National population and housing census 2000. Port Moresby: National Statistical Office. 
Peters, P.E. (2007) Challenges in land tenure and land reform in Africa: An anthropological perspective, Working Paper No. 141, Cambridge: Centre for International Development Harvard University.

Ploeg, A. (1972) Sociological aspects of Kapore settlement, in J.P. Longayroux, T. Fleming, A. Ploeg, R.T. Shand, W.F. Straatmans and W. Jonas (eds.), Hoskins development: The role of oil palm and timber, pp. 21-118. New Guinea Research Bulletin No. 49, Canberra: Australian National University.

Potter, L. and S. Badcock (2004) Tree crop smallholders, capitalism, and Adat: Studies in Riau Province, Indonesia, Asia Pacific Viewpoint 45(3): 341-356.

Reay, M. (1959a) The Kuma: Freedom and conformity in the New Guinea highlands. Melbourne: Melbourne University Press.

Reay, M. (1959b) Individual ownership and transfer of land among the Kuma, Man 109: 7882.

Reay, M. (1971) Structural co-variants of land shortage among patrilineal peoples, in R.M. Berndt and P. Lawrence (eds.), Politics in New Guinea, Perth: University of Western Australia Press.

Rigg, J. (2007) An everyday geography of the global south. London and New York: Routledge.

Ruf, F. and J. Yoddang (1999) The Sulawesi cocoa boom and its crises, Plantations, Recherche, Development July-August: 248-253.

Sillitoe, P. (1979) Give and take. Canberra: Australian National University Press.

Sjaastad, E. (2003) Trends in the emergence of agricultural land markets in sub-Saharan Africa, Forum for Development Studies 30(1): 5-28.

Yeboah, I.E.A. (2008) Ethnic emancipation and urban land claims: Disenfranchisement of the Ga of Accra, Ghana, Geographical Research 46(4): 435-445. 